\title{
Ghrelin/GHS-R1a Signaling Modulates Emotional Learning and Memory
}

\author{
Nan Li1 \\ ${ }^{1}$ Department of Physiology, Medical College of Qingdao University, Qingdao,Shandong, China 266071
}

\begin{abstract}
The amygdala complex is strongly involved in the formation of emotional memories, and GHS-R1a was found to be highly expressed in the lateral amygdala versus the central nucleus. Our previous study showed that micro-injection of ghrelin, the natural ligand of GHS-R1a, into lateral amygdala impairs memory in mice. Consistently, GHS-R1a KO mice shows enhanced memory. To explore the cellular mechanism mediating the effect of GHS-R1a signaling on emotional memory, we recorded spontaneous IPSCs and EPSCs in GHS-R1a KO and WT BL6 control mice. We found that GHS-R1a KO mice exhibited higher amplitude of IPSCs compared to that of control mice, while the EPSC We found that GHS-R1a KO mice exhibited higher frequency compared to that of control mice.
\end{abstract}

Keyword: Ghrelin; GHS-R1a; emotional learning ; emotional memory

\section{Introduction}

In 1999, Japanese scientists Kojima et al first endocrine cells from mice and human stomach and hypothalamic arcuate nucleus that he found a contains 28 amino acid polypeptide Ghrelin, and it has a strong effect on promoting growth hormone secretion ${ }^{[1-4]}$. Ghrelin can activate the type $1 \mathrm{a}$ that can promote the release of growth hormone receptor (growth hormone secretagogue receptor 1 a, GHS - R1a) and ghrelin exist two forms in the body by acetylation and acetylated $^{[5]}$. Acetylation of ghrelin is GHS - R1a endogenous ligand, and it is our major research. Instead of acetylated ghrelin levels in the blood plasma, though very high, but its receptors and the role is unclear. Ghrelin secretion from the stomach, the peripheral circulation to the central nervous system, can cross the blood brain barrier to various brain regions ${ }^{[6]}$. Ghrelin through the hypothalamus in the energy balance, sugar metabolism, plays a significant role in promoting $\operatorname{diet}^{[3,7]}$. GHS - R1a is a kind of typical G protein coupled receptors, made up of seven transmembrane regions $^{[8]}$. So far, the GHS - R1a is the only found a functional ghrelin receptor subtypes ${ }^{[9]}$. Within the central nervous system, GHS - R1a has abundantly expressed in the hypothalamus, participate in our known to promote growth hormone release, adjust the physiological function such as body weight and metabolism ${ }^{[10,11]}$. Then, according to a study of the GHS - R1a has higher expression outside the hypothalamus multiple regions, including cortex, hippocampus, amygdala, thalamic ventral tegmental area and substantia nigra compacta, such as tip GHS R1a ghrelin and its receptors on a variety of advanced features may have important role in regulating brain $^{[12,13]}$. However, GHS-R1a is also expressed in extrahypothalamic structures such as amygdala, suggesting possible involvement of the emotional learning and memory. 


\section{Materials and Methods}

\section{Slice preparation}

Mice were sacrificed and then decapitated, the brain rapidly removed to ice-cold cutting solution containing $2.5 \mathrm{mM} \mathrm{KCl}, 26 \mathrm{mM} \mathrm{NaHCO} 3,1 \mathrm{mM} \mathrm{NaH} 2 \mathrm{PO} 4,7$ mM MgSO4, 1 mM CaCl2, 30 mM Glucose, 119 mM choline chloride, $3 \mathrm{mM}$ sodium pyruvate, $1 \mathrm{mM}$ kynurenic acid, $1.3 \mathrm{mM}$ sodium L-ascorbate; aerated with $95 \% \mathrm{O} 2 / 5 \% \mathrm{CO} 2 ; \mathrm{pH}$ adjusted to 7.20 7.40. Coronal slices of $400 \mu \mathrm{m}$ were cut on a vibratome (VT-1000, Leica, Germany) and transferred to ACSF containing $85 \mathrm{mM} \mathrm{NaCl}, 2.5 \mathrm{mM} \mathrm{KCl}, 1.25 \mathrm{mM}$ NaH2PO4, $0.5 \mathrm{mM} \mathrm{CaCl} 2,4 \mathrm{mM} \mathrm{MgCl} 2,24 \mathrm{mM}$ NaHCO3, $25 \mathrm{mM}$ glucose, $50 \mathrm{mM}$ sucrose for at least $1 \mathrm{~h}$ prior to experimentation at room temperature $\left(25^{\circ} \mathrm{C}\right)$.

\section{Whole-cell patch-clamp recording}

Whole cell patch-clamp recordings in voltage-clamp mode were obtained from amygdala. The glass micropipettes (electrode impedance 4-6M $\Omega$ ) filed with a solution containing $130 \mathrm{mM} \mathrm{CsMeSO} 4,10 \mathrm{mM} \mathrm{CsCl}$, $4 \mathrm{mM} \mathrm{NaCl}, 1 \mathrm{mM} \mathrm{MgCl} 2,5 \mathrm{mM}$ MgATP, $5 \mathrm{mM}$ EGTA, $10 \mathrm{mM}$ HEPES, $0.5 \mathrm{mM}$ Na3GTP, $10 \mathrm{mM}$ phosphocreatine, $4 \mathrm{mM}$ QX-314, $\mathrm{pH}$ adjusted to 7.25 7.30 with $\mathrm{CsOH}$, osmolarity 280 290 mOsm/1. During electrophysiological recordings, slices were continuously perfused in ACSF (artificial cerebrospinal fluid, containing $120 \mathrm{mM} \mathrm{NaCl}, 3.5 \mathrm{mM} \mathrm{KCl}, 2.5 \mathrm{mM}$ $\mathrm{CaCl} 2,1.3 \mathrm{mM} \mathrm{MgSO} 4,1.25 \mathrm{mM} \mathrm{NaH} 2 \mathrm{PO} 4,26 \mathrm{mM}$ $\mathrm{NaHCO} 3,10 \mathrm{mM}$ glucose at a flow rate of $\sim 2 \mathrm{ml} / \mathrm{min}$ at room temperature.

For recording sIPSC, sontaneous synaptic currents were recording in voltage clamp at a holding potential of $+20 \mathrm{mV}$ in ASCF composed of the following $3 \mathrm{mM}$ kynuric acid. For recording sEPSC, sontaneous synaptic currents were recording in votage clamp at a hoding potential of $-70 \mathrm{mV}$ in ASCF composed of the following: $50 \mu \mathrm{M}$ AP-5 and $50 \mu \mathrm{M}$ picrotoxin..

\section{Off-line data analysis}

sEPSCs and sIPSCs were analyzed using Mini Analysis Program. Statistical analyses for all data were performed with Graphpad Prism. Spontaneous EPSCs and IPSCs were analyzed offline using the automatic detection protocol within MiniAnalysis program and subsequently checked manually for accuracy. Event counts were carried out by an experimenter blind to genotype. Event kinetics were analysed using MiniAnalysis software. Events with amplitudes between 10 and $50 \mathrm{pA}$ (EPSCs) and 15 and $70 \mathrm{pA}$ (IPSCs) were aligned by half-rise time and normalized by peak amplitude. Events displaying complex peaks were excluded from this analysis. Values in the Figures are presented as mean \pm S.E.M. Numerical values for the estimated parameters and sample sizes are indicated within the Figures. Differences between group means were assessed with appropriate unpaired Student's t tests.

\section{Results}

Lateral amygdala neurons of GHS-R1a KO mice showed similar sIPSCs and sEPSCs compared to WT controls. But there are trends that GHS-R1a KO mice exhibited higher amplitude of IPSCs compared to that of control mice, and the EPSC We found that GHS-R1a $\mathrm{KO}$ mice exhibited higher frequency compared to that of control mice.

\section{A: GHS-R1a}




\section{0pA $\frac{}{5 s}$}

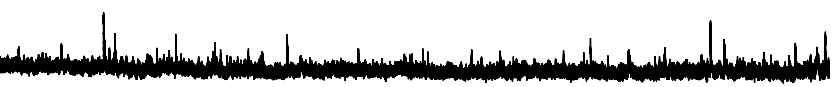

WT BL-6
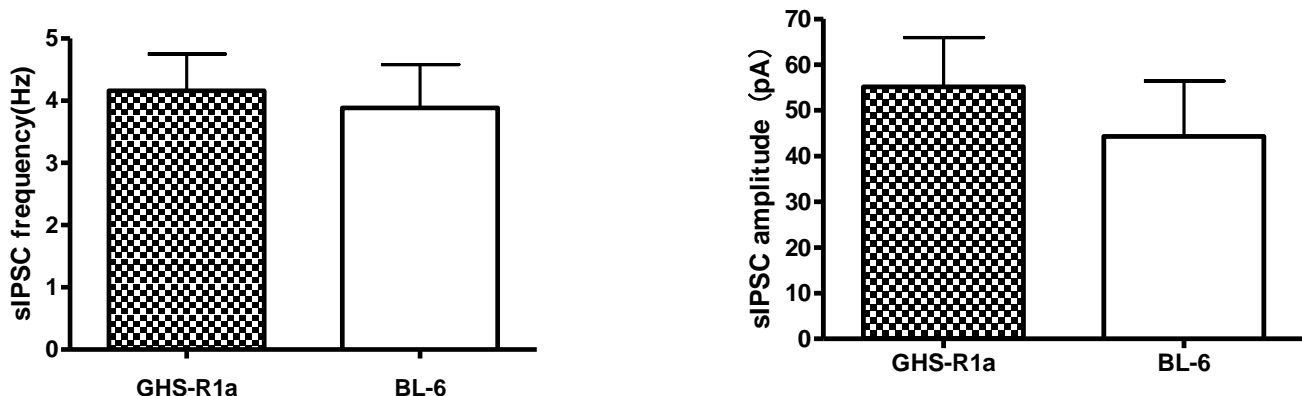

\section{B: GHS-R1a}
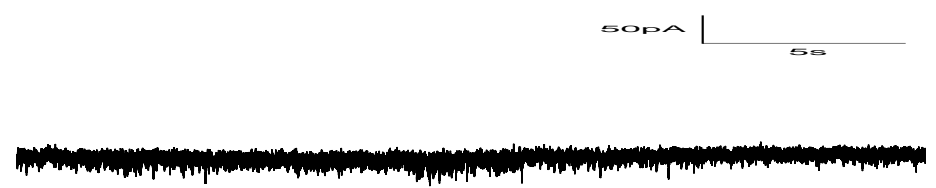

WT BL-6
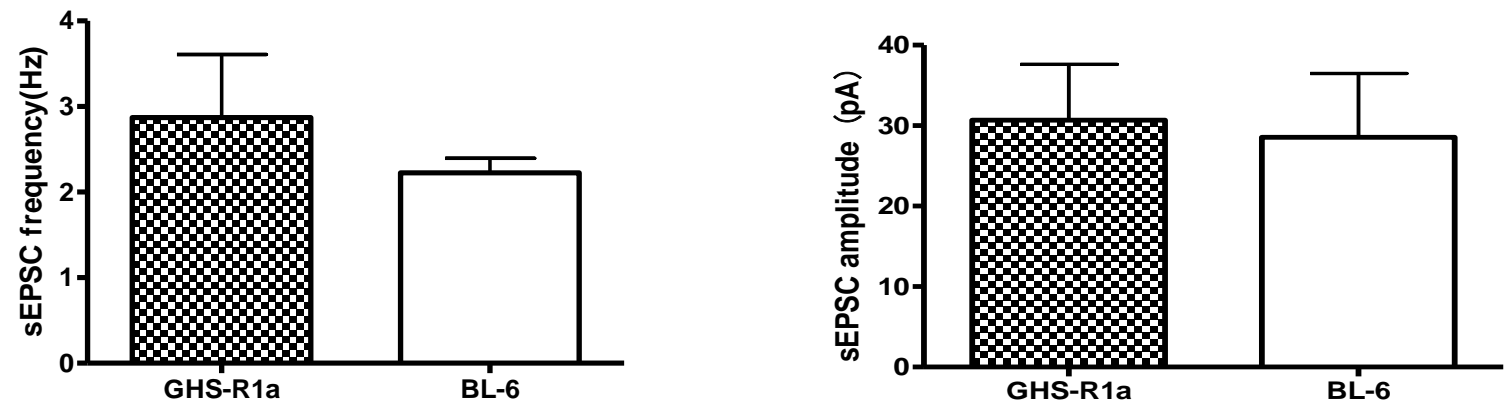

Fig.1 Spontaneous postsynaptic currents (PSCs) recorded by whole-cell patch-clamp in amygdala slices in GHS-R1a and control mice.

(A) sIPSC recorded in amygdala cells. Top, sample sIPSC traces recorded in GHS-R1a KO and WT cells.
Bottom, summary of sIPSC frequency (left) and amplitude (right) showing rising sIPSC amplitude in 
GHS-R1a KO cells compared to the WT controls. $\mathrm{n}=5$ for WT group and $\mathrm{n}=6$ for GHS-R1a KO group. (B) sEPSC recorded in amygdala cells. Top, sample sEPSC traces recorded in GHS-R1a KO and WT cells. Bottom, summary of sEPSC frequency (left) and amplitude (right) showing rising sEPSC frequency in GHS-R1a KO cells compared to the WT controls. $n=5$ for WT group and $\mathrm{n}=5$ for GHS-R1a KO group.

\section{Discussion}

Our data shows that ghrelin/GHS-R1a signaling modulates emotional learning and memory. The imbalance between inhibitory and excitatory synaptic transmission may cause increased excitatory input in lateral amygdala and thus contribute to memory improvement observed in GHS-R1a KO mice.

\section{References}

1) Kojima, M. et al. Ghrelin is a growth-hormone-releasing acylated peptide from stomach. Nature 402, 656-660, doi:10.1038/45230 (1999).

2) Howard, A. D. et al. A receptor in pituitary and hypothalamus that functions in growth hormone release. Science 273, 974-977 (1996).

3) Yang, J., Brown, M. S., Liang, G., Grishin, N. V. \& Goldstein, J. L. Identification of the acyltransferase that octanoylates ghrelin, an appetite-stimulating peptide hormone. Cell 132, 387-396, doi:10.1016/j.cell.2008.01.017, S0092-8674(08)00117-7 [pii] (2008).

4) Tschop, M., Smiley, D. L. \& Heiman, M. L. Ghrelin induces adiposity in rodents. Nature 407, 908-913, doi:10.1038/35038090 (2000).

5) Guan, X. M. et al. Distribution of mRNA encoding the growth hormone secretagogue receptor in brain and peripheral tissues.
Brain Res Mol Brain Res 48, 23-29, doi:S0169328X97000715 [pii] (1997).

6) Howard, A. D. et al. A receptor in pituitary and hypothalamus that functions in growth hormone release. Science 273, 974-977 (1996).

7) Tschop, M., Smiley, D. L. \& Heiman, M. L. Ghrelin induces adiposity in rodents. Nature 407, 908-913, doi:10.1038/35038090 (2000).

8) Guan, X. M. et al. Distribution of mRNA encoding the growth hormone secretagogue receptor in brain and peripheral tissues. Brain Res Mol Brain Res 48, 23-29, doi:S0169328X97000715 [pii] (1997).

9) Mingaud, F. et al. The hippocampus plays a critical role at encoding discontiguous events for subsequent declarative memory expression in mice. Hippocampus 17, 264-270, doi:10.1002/hipo.20262 (2007)

10) Eichenbaum, H. The hippocampus and declarative memory: cognitive mechanisms and neural codes. Behav Brain Res 127, 199-207, doi:S0166432801003655 [pii] (2001).

11) Fenton, A. A. et al. Attention-like modulation of hippocampus place cell discharge. J Neurosci 30, 4613-4625, doi:10.1523/JNEUROSCI.5576-09.2010,30/13/4613 [pii] (2010).

12) Zigman, J. M., Jones, J. E., Lee, C. E., Saper, C. B. \& Elmquist, J. K. Expression of ghrelin receptor mRNA in the rat and the mouse brain. J Comp Neurol 494, 528-548, doi:10.1002/cne.20823 (2006).

13) Decker, M. W., Pelleymounter, M. A. \& Gallagher, M. Effects of training on a spatial memory task on high affinity choline uptake in hippocampus and cortex in young adult and aged rats. J Neurosci 8, 90-99 (1988). 